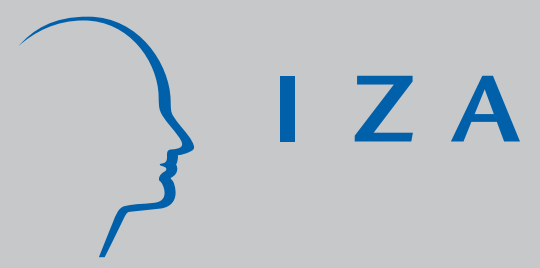

IZA DP No. 1156

Earnings and Community College Field of Study Choice in Canada

Brahim Boudarbat

May 2004 


\title{
Earnings and Community College Field of Study Choice in Canada
}

\author{
Brahim Boudarbat \\ University of British Columbia \\ and IZA Bonn
}

\author{
Discussion Paper No. 1156 \\ May 2004
}

\author{
IZA \\ P.O. Box 7240 \\ 53072 Bonn \\ Germany \\ Phone: +49-228-3894-0 \\ Fax: +49-228-3894-180 \\ Email: iza@iza.org
}

\begin{abstract}
Any opinions expressed here are those of the author(s) and not those of the institute. Research disseminated by IZA may include views on policy, but the institute itself takes no institutional policy positions.

The Institute for the Study of Labor (IZA) in Bonn is a local and virtual international research center and a place of communication between science, politics and business. IZA is an independent nonprofit company supported by Deutsche Post World Net. The center is associated with the University of Bonn and offers a stimulating research environment through its research networks, research support, and visitors and doctoral programs. IZA engages in (i) original and internationally competitive research in all fields of labor economics, (ii) development of policy concepts, and (iii) dissemination of research results and concepts to the interested public.
\end{abstract}

IZA Discussion Papers often represent preliminary work and are circulated to encourage discussion. Citation of such a paper should account for its provisional character. A revised version may be available on the IZA website (www.iza.org) or directly from the author. 


\title{
ABSTRACT \\ Earnings and Community College Field of Study Choice in Canada*
}

In this paper, we estimate a structural model of choice of field of study by community college students. We use data from the Canadian Survey of Graduates for 12,871 individuals who successfully completed their programs in Canadian community colleges (CEGEPs in Quebec) in 1990 and 1995. Over this period, the returns to fields such as health declined relative to other fields such as science and engineering, a fact that provides useful leverage for identifying the impact of earnings on the choice of field of study. Results indicate that the probability of selecting a specific college field of study depends significantly on expected earnings in this field relative to other fields. We also find that women put less weight on earnings than men when choosing a field of study and those students who were employed prior to starting college are more sensitive to earnings variations across fields of study than students with no prior work experience.

JEL Classification: J24, J31

Keywords: Canada, community college, field of study choice, selection bias

\author{
Brahim Boudarbat \\ Department of Economics \\ University of British Columbia \\ 997-1873 East Mall \\ Vancouver, B.C., V6T 1 Z1 \\ Canada \\ Tel.: +1 6048228624 \\ Fax: +1 6048225915 \\ Email: brahim@interchange.ubc.ca
}

\footnotetext{
* I would like to thank Thomas Lemieux, David Green, Claude Montmarquette, Dwayne Benjamin, Nour Meddahi and Martin Fournier for many useful comments and suggestions. I also thank participants at the empirical micro seminar at the University of British Columbia, TARGET workshop and Canadian Economics Association 2003 Conference (Ottawa) for their helpful comments. Many thanks also go to Statistics Canada for providing the data used in this study. I gratefully acknowledge financial assistance from SSHRCC INE Grant "Globalization, technological revolutions and education."
} 


\section{Introduction}

Human capital theory provides a rich set of empirical predictions about the relationship between schooling choices and labour market outcomes by viewing schooling (or on-the-job training) as an optimal choice based on comparing cost and benefits. The basic principle is that individuals should keep investing in schooling as long as marginal benefits exceed marginal costs. A large number of studies show compelling evidence that schooling is associated with higher earnings (see Card, 1999, for a recent review). Therefore, empirical evidence strongly supports the view that investments in schooling yield positive pecuniary returns, which is a key ingredient of the human capital approach. Interestingly, however, a much smaller number of studies have directly addressed the more central principle human capital theory, namely that schooling (or other) investments are determined by a comparison of marginal returns and marginal costs. ${ }^{1}$

A major obstacle in studying the determinants of schooling investment is the lack of credible variation in the costs and benefits of schooling. Ideally, one would like to estimate the effect of exogenous differences in both costs (tuitions, opportunity cost, etc.) and benefits (marginal return to schooling) on schooling decision in a cross-section of individuals. While regional differences in tuitions (Kane, 1994) and other costs are arguably exogenous to the schooling decision, individual-specific rates of returns are plagued by a fundamental selection problem. The problem is that earnings are generally only observed after the schooling investment has been completed. Since earnings before schooling is completed are generally missing, the earnings gain from extra schooling (marginal return) decision cannot be measured directly. Following Willis and Rosen (1979), the standard solution to this problem is to estimate selection-corrected earnings equations for different schooling levels and use these estimates to construct

\footnotetext{
${ }^{1}$ Willis and Rosen (1979) estimate a structural probit model that links various costs and benefits to the decision to attend college. See also Keane and Wolpin (1997) for a more recent example of structural estimation of the schooling decision.
} 
a predicted return to schooling for each individual. The reliability of this econometric approach critically depends, however, on the availability of instruments that can predict differences in rates of returns across individuals without directly affecting the choice of schooling.

In this paper, we use repeated cross-sections on the choice of field of study of Canadian college students to identify the direct impact of returns to schooling on educational choices. More specifically, we estimate how differences in returns in different fields affect decision of choosing one field over the other. From an empirical point of view, there are some important advantages in looking at choice of fields of study (intensive margin) instead of the decision to pursue more schooling (extensive margin). First, we argue that both opportunity costs and direct costs (tuition) do not depend on field of study. The cost of studying in different fields is thus implicitly controlled for when estimating the impact of other factors on field of study. In a pure cross-section, however, the identification of the effect of return to field of study on field choice remains problematic. The problem is that observed wage differences across fields may reflect selection of workers instead of the causal effect of field of study on earnings for given individuals.

One key contribution of the paper is thus to exploit two cross-sections (and cohorts) of young workers who completed college in 1990 and 1995 from the Canadian National Survey of Graduates (SOG). We argue that combining cross-field and cross-time variation provides a credible source of variation in the returns to field of study. The idea is that shocks that hit sectors can change the returns to studying in a particular field and be used to see how field choice of new cohorts of students respond to these changing conditions. The first half of the 1990s is an interesting period to study since relative wage and employment prospects for different fields of study changed substantially during this period. In particular, budget crises at the federal and provincial levels lead to dramatic cuts in health care funding starting in 1992 (Vujicic, 2003). By contrast, the labour market for graduates in science-oriented fields (computer programming, etc.) was much stronger during this period. These kinds of sectoral shocks 
provide useful leverage for evaluating how responsive are human capital investments (in different fields of study) to changes in labour market conditions.

Our focus on community college students in Canada is a consequence of several factors. First, Canada has a very large fraction of college graduates as compared to most OECD countries. ${ }^{2}$ Understanding the educational decisions at this particular level is thus essential to overall educational policies in Canada. In most cases, college graduates will have completed two or three years specialized program in a community college (CEGEP in Quebec). Unlike universities where most students choose the field of study (major) after a year or two of study, most college students first enrol into a specific program. Our model of choice of field study is thus particularly well suited for the college-level decision. One final advantage of studying college field of study in Canada is that relatively large samples of college graduates are available in the SOG in both the 1990 and 1995 cohorts of graduates.

The rest of the paper is organized as follows. In Section 2, we present a structural model describing the choice of field of study. Earnings in each field of study are first adjusted of selection bias, and then predicted earnings are included as covariates in the selection equations. Section 3 describes data used in this study. The sample consists of 5,219 individuals who graduated in 1990 pooled with 7,562 individuals who graduated in 1995. In Section 4, we discuss the empirical results of the study. We find that expected earnings significantly influence the choice of the college field, a fact which agrees with previous studies (see for example Berger, 1988, and Montmarquette, Cannings and Mahseredjian, 2002). We also find that women are less influenced by earnings relative to men, a fact which supports the results of Montmarquette, Cannings and Mahseredjian (2002). In addition, individuals who were employed prior to starting college put more weight on earnings when choosing their field of study. Our results also suggest that many other factors (such as parents' education, family affluence, etc.) play a significant role in this choice. Section 5 concludes the study.

\footnotetext{
${ }^{2}$ In 2000, this fraction was $28.1 \%$ in Canada versus only $6.6 \%$ in U.S. and $9.4 \%$ all OECD countries pooled (OECD, 2002).
} 


\section{Econometric Specifications}

A life-cycle approach suggests that predicted future earnings are determinant for education choices. Indeed, applying the model of endogenous schooling presented by Card (2000) to the choice of fields of study, it follows that students choose to major in fields that maximize their lifetime earnings. More precisely, assume that a student has to choose a field of study among $M$ competing fields. Assuming an infinite planning horizon starting at the time the choice is made (i.e. time of enrolment in a given field), the discounted lifetime utility corresponding to enrolment in field $m(m=1, \ldots, M)$ and given a profile of consumption $c(t)$ is:

$$
V(m, c(t))=\int_{0}^{l_{m}}\left[u(c(t))-\phi_{m}(t)\right] e^{-\rho t} d t+\int_{l_{m}}^{\infty} u[c(t)] e^{-\rho t} d t
$$

where $l_{m}$ is the length of studies in field $m, u($.$) is an increasing concave utility function, \phi_{m}$ is a convex function reflecting relative disutility of studying in this field versus working (or enrolling in a different field), and $\rho$ is the personal discount rate.

Let $Y_{m}(t)$ denote the real earnings for a worker who graduated in field $m$ and who has $t$ units of work experience, $p(t)$ denote earnings from a possible part time job while studying at time period $t$, and $q_{m}(t)$ denote tuition per unit of time. We also assume that individuals can borrow and lend freely at a fixed interest rate $R$. The discounted lifetime earnings conditional on enrolment in field $m$ is given by:

$$
W_{m}=\int_{0}^{l_{m}}\left[p(t)-q_{m}(t)\right] e^{-R t} d t+\int_{l_{m}}^{\infty} Y_{m}\left(t-l_{m}\right) e^{-R t} d t
$$

The intertemporal budget constraint is then given by:

$$
\int_{0}^{\infty} c(t) e^{-R t} d t=W_{m}
$$


Conditional on enrolment in field $m$, the individual's optimal consumption path maximizes:

$$
\Omega(m, c(t), \lambda)=V(m, c(t))-\lambda\left[\int_{0}^{\infty} c(t) e^{-R t} d t-W_{m}\right]
$$

where $\lambda$ is a LaGrange multiplier. Assuming that $u(c(t))=\ln (c(t))$ and $\rho=R$, first order conditions imply that an individual's optimal consumption path is $c^{*}(t)=\rho W_{m}$. At each time period $t$, the student consumes a constant share of his or her lifetime earnings equal to his or her personal discount rate.

Ignoring the disutility while studying $\left(\phi_{m}\right)$, the optimal discounted lifetime utility conditional on enrolment in the field $m$ simplifies to:

$$
U^{*}(m)=\frac{\ln (\rho)+w_{m}}{\rho}
$$

where $w_{m}=\ln \left(W_{m}\right)$.

Since the personal discount rate $\rho$ is constant, maximizing the discounted lifetime utility amounts to maximizing the log discounted lifetime earnings. Therefore, an individual will choose a major with the highest log discounted lifetime earnings. Supporting this result, several empirical studies show compelling evidence that anticipated earnings after graduation significantly influence field of study choice (see for example Weiss, 1971, Polachek, 1978, Berger 1988, Paglin and Rufolo, 1990, and more recently Montmarquette, Cannings and Mahseredjian, 2002). Field choice is consistent with an earnings-maximization problem.

Specification of the econometric model presented below is adapted to the data used in this study. We define (for convenience we omit the subscript $i$ related to individual):

$$
U_{m}^{*}=\alpha y_{m}+V \theta_{m}+\xi_{m}, m=1, \ldots, M
$$


as the expected level of indirect utility if the individual chooses the field of study $m$, expressed as a linear relation of $\log$ annual earnings in field $m\left(y_{m}\right),{ }^{3}$ a vector of observed characteristics that influence students' choices $(V)$, and a random component that captures unobserved variables $\left(\xi_{m}\right)$. Coefficient $\alpha$ in Equations (6) is the same for all fields of study, while the vector $\theta_{m}$ is specific to each field. We expect a positive sign for $\alpha$.

Notice that we use annual earnings instead of the lifetime earnings. Reasons for this are that the calculation of the lifetime earnings requires the value of the annual growth rate of earnings in each field and the value of the individual discount rate. The data we use in our study (see Section 3 ) does not make it possible to estimate the annual growth rate of earnings correctly, since observed earnings are from recent and young graduates. In addition, the discount rate is unknown. ${ }^{4}$ The limitations of being forced into this approach (use of annual earnings of new graduates) is that, for example, a field with higher beginning earnings may end up with lower lifetime earnings if earnings increase in a lower rate in this field of study compared to other fields. Berger (1988) argue that students are likely to select fields of study associated with greater streams of future earnings rather than fields with higher beginning earnings. Yet, other studies support that starting wages are important in students' choices (see for example Freeman, 1976, Willis and Rosen, 1979).

Earnings equation in each field $m$ is given by:

$$
y_{m}=X \beta_{m}+\varepsilon_{m}, \quad m=1 \text { to } M
$$

\footnotetext{
${ }^{3}$ In our data, annual earnings are observed two years after graduation

${ }^{4}$ Willis and Rosen (1979) consider the discount rate as a linear function of some observed variables and a random component. On the other hand, Berger (1988) considers a discount rate of 0.05 .
} 
$X$ is a vector of covariates and $\varepsilon_{m}$ is a random component satisfying $E\left(\varepsilon_{m} \mid X\right)=0$ and $\varepsilon_{m} \sim N\left(0, \sigma_{m}\right) . y_{m}$ is to be interpreted as earnings (after graduation) expected by a student at the time the choice is made.

A student chooses the field that maximizes his or her indirect utility. The latter is not observable. We rather observe students' choices given by the following dummy variables:

$$
\begin{aligned}
& d_{m}=1, \text { if } U_{m}^{*}=\operatorname{Max}\left(U_{1}^{*}, U_{2}^{*}, \ldots, U_{M}^{*}\right), \text { a student chooses field } m \\
& d_{m}=0, \text { otherwise, } m=1, \ldots, M \\
& \sum_{1}^{M} d_{m}=1
\end{aligned}
$$

Hence, the selection rule is:

$$
\operatorname{Pr}(\text { choose Field } m)=\operatorname{Pr}\left(d_{m}=1\right)=\operatorname{Pr}\left(U_{m}^{*}>U_{j}^{*}\right), j=1, \ldots, M, j \neq m
$$

Assuming that stochastic terms $\xi_{m}, m=1$ to $M$, are independent and identically Gumbell (or Type I extreme-value) distributed leads to the conditional multinomial logit of McFadden (1973). The probability of choosing field $m$ is therefore:

$$
P_{m}=\operatorname{Prob}\left(d_{m}=1 \mid V,\left\{y_{s}\right\}_{s=1 \text { to } M}\right)=\frac{\exp \left(\alpha y_{m}+V \theta_{m}\right)}{\sum_{s=1}^{M} \exp \left(\alpha y_{s}+V \theta_{s}\right)}
$$

In order to identify the model, we arbitrarily set $\theta_{l}=0$. The remaining vectors of parameters $\theta_{m}, m=2$ to $M$, will measure the variation relative to the first field of study.

Here, we assume that all parameters and distributions are perfectly known to students at the time they make their choices. Moreover, we assume that observed choices are the first ones made by students (i.e. a student has free access to any field of his or her choice). 
The structural model is given by Equations (6) and (7). Estimating earning equations independently of selection equations introduces a selection bias in estimates since earnings in each field of study are only observed for those who select this field and only after the schooling investment has been completed. The standard solution to this problem is to estimate selection-corrected earnings equations for different schooling levels and use these estimates to construct a predicted return to schooling for each individual. Then, predicted adjusted values are included as covariates in selection equations (Equations 6$).{ }^{5}$ Yet, this procedure produces same predicted earnings for individuals having same observed characteristics included in earnings equations (i.e. vector $X$ in Equation (7)). Consequently, students face same set of returns and thus, there is no reason they would not all choose the most lucrative field. Of course, this is not really what would happen. In reality, different people have different talents and stand to earn different returns from different fields of study because the jobs associated with those fields use talents in different ways. What sample selection corrections then do is answer the question, what would the returns be if we put a randomly selected person in each of the fields. A solution to this problem is to add a random term representing heterogeneity among individuals to the predicted earnings. For the sake of simplicity, we assume that such heterogeneity along with differences in tastes toward study programs and other unobserved variables are all caught by the random terms $\xi_{m}$ in Equation (6), and that the latter are still independent and identically type I extreme-value distributed.

On the other hand, the selection correction when using cross-sectional data critically depends on the availability of instruments that can predict differences in rates of returns across individuals without directly affecting the choice of field of study. In absence of such instruments, it is not possible to disconnect individual effect from field effect when comparing earnings across fields of study. However, one feature of our data is combining cross-field and cross-time variations (data from two different

\footnotetext{
${ }^{5}$ Willis and Rosen (1979) and Berger (1988) adopt the same approach. See also Lee (1978) who uses a two-stage probit estimation to study unionism and wage rates. The predicted adjusted wage gain from joining a union is included as covariate variable along with other observed variables in a probit maximum likelihood procedure (binary choice). Lee (1976) has proved the consistency of this two stage probit estimation.
} 
cohorts), which provides a credible source of variation in the returns to field of study and helps in identifying the parameters of our model. Nonetheless, we still rely on some exclusion restrictions. For instance, parents' education levels are included as explanatory variables in the selection equation but they are excluded from the earnings equations. This imply that parents may influence their children choices but do not contribute in determining their wages.

Finally, one may argue that students may be influenced by observed earnings instead of self-selection corrected ones. In this paper, we also discuss the effect of ignoring slef-selection on the estimated weight put on earnings when choosing a field of study.

A reduced form of the selection equations (6) is obtained by substituting (7) into (6):

$$
\begin{aligned}
U_{m}^{*} & =X \pi_{m}+V \theta_{m}+\xi_{m},{ }^{6} \\
& =Z \gamma_{m}+\xi_{m}, m=1, \ldots, M
\end{aligned}
$$

where $\pi_{m}=\alpha \beta_{m}, Z=[X, V]$ and $\gamma_{m}=\left[\pi_{m}, \theta_{m}\right]^{\prime}$. Hence, the probability of choosing field of study $m$

is: $\quad P_{m}=\operatorname{Prob}\left(d_{m}=1 \mid V, X\right)=\frac{\exp \left(Z \gamma_{m}\right)}{\sum_{s=1}^{M} \exp \left(Z \gamma_{s}\right)}$

The multinomial logit-OLS two stage estimation method of Lee $(1983)^{7}$ suggests adjusting for selfselection bias in earnings equations by introducing a correction term:

$$
y_{m}=X \beta_{m}+\sigma_{m} \rho_{m}\left[-\phi\left(\Phi\left(P_{m}\right)\right) / P_{m}\right]+u_{m}, \quad m=1 \text { to } M
$$

\footnotetext{
${ }^{6}$ We eliminate the random component $\varepsilon_{m}$ by using $E\left(y_{m}\right)$ instead of $y_{m}$. Otherwise, the random terms in the selection Equations (11) will not be longer independent and identically Type I extreme-value distributed.

${ }^{7}$ For the sake of comparison, we also used the new procedure suggested by Bourguignon, Fournier and Gurgand (2001). While the two methods lead to different conclusions with regard the presence and magnitude of selfselection in estimated earnings equations, the estimated weights put by students on earnings when choosing a field of study are, however, comparable.
} 
where $\sigma_{m}$ is the standard deviation of $\varepsilon_{m}, \rho_{m}$ is the correlation coefficient between $\varepsilon_{m}$ and a transformation of the errors in the selection equation (11), $\phi($.$) and \Phi($.$) are respectively the density$ and cumulative density functions of a standard normal distribution, and $u_{m}$ is an error term with zero expectation. Finally, $\sigma_{m} \rho_{m}\left[-\phi\left(\Phi\left(P_{m}\right)\right) / P_{m}\right]$ is the expected value of $\varepsilon_{m}$ conditional on field $m$ being selected, where $P_{m}$ is the probability of selecting field of study $m$. Practically, we estimate $\gamma_{m}$ in (11) by conditional logit analysis and obtain estimates $\hat{\gamma}_{m}$. Probabilities $P_{m}$ and then $\lambda_{m}=-\phi\left(\Phi\left(P_{m}\right)\right) / P_{m}$, are estimated using estimates $\hat{\gamma}_{m}$. The parameters $\left(\beta_{m}\right)$ of the earnings equation are estimated consistently by regressing the log of observed earnings in each field of study on

$X$ and $\hat{\lambda}_{m}$. Afterward, predicted adjusted earnings are calculated for each individual in each field of study and then inserted into Equations (6) as covariates along with other observed variables in $V$. The covariance matrix is approximated as if the predicted adjusted earnings are the exact exogenous variables (see Lee, 1978, for a similar approach using a two-stage probit model to study unionism and wage rates.)

\section{Description of the Data}

The data used in this study is drawn from the Canadian Survey of Graduates (SOG) conducted by Statistics Canada in partnership with Human Resources Development Canada. The survey concerns graduates from Canadian public post-secondary educational institutions (universities, colleges, trade schools) who have successfully completed their programs two years prior to the date of the survey. The survey excludes graduates from private post-secondary educational institutions, completers of continuing-education programs (unless these led to a degree, diploma or certificate), part-time trade course graduates and graduates of provincial apprenticeship programs and graduates living outside of Canada at the time of the survey. The survey aims at determining such factors as the extent to which 
graduates of post-secondary programs had been successful in obtaining employment since graduation, the relationship between the graduates' programs of study and the employment subsequently obtained, the graduates' job and career satisfaction, the rates of under-employment and unemployment, the type of employment obtained related to career expectations and qualification requirements as well as the influence of post-secondary education on occupational achievement.

Our sample is drawn from the 1992 and 1997 SOGs which concern respectively 1990 and 1995 graduates. The sample includes only graduates from community colleges (CEGEPs in Quebec) who actually graduated during the reference calendar years (i.e. either in 1990 or 1995). ${ }^{8}$ We also trim all wage observations with annual earnings (in 1997\$) below \$6,000 (274 persons) or above \$200,000 (6 persons), and only retain individuals age 16-65. The final sample consists of 5,219 individuals who graduated in 1990 pooled with 7,562 individuals who graduated in 1995, for a total of 12,781 observations. To facilitate empirical analysis, we consider five broadly defined fields of study (1) "Education, Fine Arts and Humanities," (2) “Social Sciences," (3) "Business, Commerce," (4) "Health" and (5) "Sciences."

\section{Table 1}

Distribution of Graduates over Fields of Study

\begin{tabular}{ccccccc}
\hline $\begin{array}{c}\text { Year of } \\
\text { graduation }\end{array}$ & $\begin{array}{c}\text { Education, } \\
\text { Fine Arts, } \\
\text { Humanities }\end{array}$ & $\begin{array}{c}\text { Social } \\
\text { Sciences }\end{array}$ & $\begin{array}{c}\text { Business, } \\
\text { Commerce }\end{array}$ & Health & Sciences & Total \\
\hline $1990(1)$ & $18.66 \%$ & $9.36 \%$ & $26.2 \%$ & $18.61 \%$ & $27.17 \%$ & $100 \%$ \\
$1995(2)$ & $18.12 \%$ & $12.33 \%$ & $24.66 \%$ & $15.69 \%$ & $29.2 \%$ & $100 \%$ \\
(2)-(1) & $\mathbf{- 0 . 5 4 \%}$ & $\mathbf{+ 2 . 9 7 \%}$ & $\mathbf{- 1 . 5 4 \%}$ & $\mathbf{- 2 . 9 2 \%}$ & $\mathbf{+ 2 . 0 3 \%}$ & - \\
\hline
\end{tabular}

Note: Theses figures are calculated using the whole samples from 1992 and 1995 SOGs and are weighted

The main feature of our sample is that it allows seeing how field choices of new cohorts of students respond to shocks that hit sectors. The first half of the 1990s is an interesting period to study since relative wage and employment prospects for different fields of study changed substantially during this

\footnotetext{
${ }^{8}$ Data files include some workers who graduated in 1989 or 1991 for 1992 SOG, and in 1994 or 1996 for 1997 SOG.
} 
period. In particular, budget crises at the federal and provincial levels lead to dramatic cuts in health care funding starting in 1992 (Vujicic, 2003). By contrast, the labour market for graduates in scienceoriented fields (computer programming, etc.) was much stronger during this period. These kinds of sectoral shocks provide useful leverage for evaluating how responsive are human capital investments (in different fields of study) to changes in labour market conditions.

\section{Table 2}

Mean Annual Earnings Two Years after Graduation, by Fields of Study and Gender (\$’000, in 1997\$)

\begin{tabular}{|c|c|c|c|c|c|c|c|}
\hline & $\begin{array}{c}\text { Year of } \\
\text { graduation }\end{array}$ & $\begin{array}{l}\text { Education, } \\
\text { Fine Arts, } \\
\text { Humanities }\end{array}$ & $\begin{array}{c}\text { Social } \\
\text { Sciences }\end{array}$ & $\begin{array}{l}\text { Business, } \\
\text { Commerce }\end{array}$ & Health & Sciences & Total \\
\hline \multirow{5}{*}{$\begin{array}{c}\text { Both } \\
\text { Genders }\end{array}$} & 1990 & 22.83 & 26.24 & 23.67 & 30.21 & 27.56 & 26.23 \\
\hline & & (11.80) & $(14.06)$ & (10.32) & $(9.57)$ & (10.03) & (11.08) \\
\hline & 1995 & 22.77 & 26.12 & 25.69 & 27.82 & 32.18 & 27.56 \\
\hline & & (10.92) & $(11.70)$ & (12.22) & (12.58) & (13.36) & $(12.81)$ \\
\hline & Variation & $-0.26 \%$ & $-0.46 \%$ & $+8.53 \%$ & $-7.91 \%$ & $+16.76 \%$ & $+5.07 \%$ \\
\hline \multirow{5}{*}{ Males } & 1990 & 24.01 & 27.85 & 27.41 & 33.59 & 28.17 & 28.12 \\
\hline & & (11.43) & $(11.60)$ & (11.91) & $(7.34)$ & $(9.70)$ & (10.56) \\
\hline & 1995 & 27.08 & 29.40 & 30.48 & 30.40 & 33.82 & 31.85 \\
\hline & & (16.17) & $(12.22)$ & (15.42) & (12.88) & (13.63) & $(14.26)$ \\
\hline & Variation & $+12.79 \%$ & $+5.57 \%$ & $+11.20 \%$ & $-9.50 \%$ & $+20.06 \%$ & $+13.26 \%$ \\
\hline \multirow{5}{*}{ Females } & 1990 & 22.44 & 25.17 & 21.88 & 29.43 & 25.38 & 24.89 \\
\hline & & (11.90) & $(15.41)$ & $(8.93)$ & $(9.86)$ & (10.89) & (11.24) \\
\hline & 1995 & 21.33 & 24.30 & 23.27 & 27.36 & 26.70 & 24.39 \\
\hline & & (7.99) & $(11.00)$ & $(9.35)$ & (12.48) & (10.69) & (10.57) \\
\hline & Variation & $-4.95 \%$ & $-3.46 \%$ & $+6.35 \%$ & $-7.03 \%$ & $+5.20 \%$ & $-2.01 \%$ \\
\hline
\end{tabular}

Note: All wage observations with annual earnings below $\$ 6,000$ are trimmed. Figures in parentheses are standarddeviations

The aforementioned changes in health and sciences are reflected by the evolution of earnings by field of study. The mean annual earnings (in 1997 dollars) two years after graduation increased by about 5.07\% between 1992 and 1997 (Table 2). However, this overall growth is the result of the substantial increase of graduate earnings in "Sciences" $(+16.76 \%)$ and "Business and Commerce" $(+8.53 \%)$. On the other hand, earnings dropped significantly for "Health" graduates (-7.91\%). Furthermore, mean earnings increased by $13.26 \%$ for male graduates and decreased by $2.01 \%$ for female graduates. Meanwhile, the share of the field "Health" in the population of graduates significantly dropped going from $18.61 \%$ in 
1990 to $15.69 \%$ in 1995 , while at the same time the share of "Sciences" increased by two points from $27.17 \%$ to $29.2 \%$ during the same period (Table 1 ). There is, however, a mis-match in timing between expected earnings and enrolment decisions in some fields of study. For instance, the share of "Business and Commerce" graduates decreased (-1.54\%) despite the increase in the mean annual earnings. Also, the share of "Social Sciences" graduates significantly increased $(+2.97$ points) even with a slow decrease in their earnings.

The modeling assumes that students accurately forecast wages for the time they graduate, yet decisions are made a couple of years (the duration of studies) in advance of market conditions. Still, a mis-match in timing between expected earnings and enrolment decisions is possible under this assumption. For instance, if the 1990 graduate wages were a more important determinant of the 1995 graduates' initial enrolment decisions, there may be "hog cycles" where students over-invest in "hot fields," and ultimately depress the wages when they graduate. On the other hand, one can wonder whether "Health" students did anticipate the contraction of health budgets in the 1990's. If they did not, we cannot link the ultimately low wages they experienced to their expectations when they started college. Of course, pecuniary variables are not the unique variables that drive students' choices. Nonmarket variables such as interests and abilities also exert a significant impact on those choices (see for example Fiorito and Dauffenbach, 1982), but data availability does not make it possible to control for these variables. Nonetheless, a greater part of graduates (67\% of 1990 graduates and $71 \%$ of 1995 graduates) affirm that they would have selected the same program given their experience since graduation (see Table 3). Actually, it is surprising that the proportion of graduates who would have selected the same field of study increased among "Health" graduates despite the significant decrease in their earnings. Among those who would have selected a different program of study, 39\% of 1990 graduates and $37.9 \%$ of 1995 graduates blame the lack of jobs in their fields of study. Over time, the proportion of graduates pointing the finger at the same reason increased in "Health" (45.5\% in 1995 versus $29.7 \%$ in 1990) while it decreased in "Sciences" (37.8\% in 1995 versus 43.7\% in 1990). With regard to other reasons, 
respectively $8 \%$ and $5.8 \%$ of 1990 and 1995 graduates evoke their dissatisfaction with the salary, while respectively $13.6 \%$ and $15.2 \%$ refer to a change of interest. Finally, only $10.3 \%$ and $2.3 \%$ respectively of 1990 and 1995 graduates who would have selected a different field of study affirm that current choice of field of study was not their first. The latter figures corroborate the assumption in the modeling that observed field of study choices are first choices made by students.

\section{Table 3}

Proportion of Graduates who would Have Selected the Same Field of Study Given their Experience since Graduation

\begin{tabular}{ccccccc}
\hline $\begin{array}{c}\text { Year of } \\
\text { graduation }\end{array}$ & $\begin{array}{c}\text { Education, } \\
\text { Fine Arts, } \\
\text { Humanities }\end{array}$ & $\begin{array}{c}\text { Social } \\
\text { Sciences }\end{array}$ & $\begin{array}{c}\text { Business, } \\
\text { Commerce }\end{array}$ & Health & Sciences & Total \\
\hline 1990 & 0.67 & 0.68 & 0.62 & 0.65 & 0.71 & 0.67 \\
1995 & 0.72 & 0.68 & 0.70 & 0.69 & 0.74 & 0.71 \\
Total & 0.70 & 0.68 & 0.67 & 0.67 & 0.73 & 0.69 \\
\hline
\end{tabular}

Note: Theses figures are calculated using the whole samples from 1992 and 1995 SOGs

On the other hand, graduates tend to confirm the view that the choice of field of study is consistent with an earnings-maximization problem, a fact that is also coherent with our modeling. Indeed, over two thirds of graduates reported that "looking to improve the chances of a good income" was a very important factor in their choice. Only few graduates reported this factor as unimportant. There are no significant differences on this issue between genders.

Other descriptive statistics are reported in Table 4. The average age of college graduates at the time of the survey (two years after graduation) is 27.1 years, and it is slightly high for "Health" graduates. In addition, female graduates are dominant in the population of graduates (58\%), particularly in "Health" (83\%) and "Education, Fine Arts and Humanities" (75\%). In contrast, they are rare in "Sciences" (only 22\%). This distribution is almost the same in 1990 and 1995. The scarcity of women in "Sciences" could be related to their anticipated labour force participation. Students looking for intermittent labour force participation or female students with higher expected fertility would avoid fields (such as science) requiring a high level of on-the-job training and tend to choose majors that are progressively less subject 
to atrophy and obsolescence (Polachek, 1978; Blakemore \& Low, 1984). Furthermore, many people seem to believe in the notion that there are "old-boys" networks in some professions that make them hard to getting into for women. This hypothesis cannot be rejected by our data.

With regard to spoken languages, $63 \%$ of graduates speak only English and only 23\% are bilingual. Obviously, a very large fraction of graduates come from two provinces, Ontario (43\%) and Quebec (24\%). Students from Ontario tend to graduate mainly in "Education, Fine Arts and Humanities" and "Social Sciences," whereas those from Quebec seem to privilege "Health" and "Sciences." Moreover, secondary education is the most important level of education of graduates' parents especially mothers ( $43 \%$ of fathers and $51 \%$ of mothers). On the other hand, only $10 \%$ of fathers and $15 \%$ of mothers carried out studies at the same level as their children (i.e. community college). In view of this information, the choice of college studies does not seem to be inherited from parents.

The sample is also characterized by the large fraction of graduates who were working before enrolling in their programs (43\%). This fraction is high across all fields, ranging between $39 \%$ in "Business and Commerce" and $46 \%$ in "Health." We use this information to examine whether work experience prior to starting college studies influences the weights put on expected earnings when choosing a field of study. Finally, $44 \%$ of graduates reported student loans as an important source of funding studies. Graduates in "Health" (50\%) and "Social Sciences" (47\%) counted more than others on such source of funding studies. We use this variable as a proxy for the family income, which is not available in our data. 


\section{Table 4}

Descriptive Statistics

\begin{tabular}{|c|c|c|c|c|c|c|}
\hline & $\begin{array}{l}\text { Education, } \\
\text { Fine Arts, } \\
\text { Humanities }\end{array}$ & $\begin{array}{c}\text { Social } \\
\text { Sciences }\end{array}$ & $\begin{array}{l}\text { Business, } \\
\text { Commerce }\end{array}$ & Health & Sciences & Total \\
\hline Age & $\begin{array}{l}26.43 \\
(6.71)\end{array}$ & $\begin{array}{l}27.66 \\
(7.99)\end{array}$ & $\begin{array}{l}26.48 \\
(6.72)\end{array}$ & $\begin{array}{l}28.51 \\
(7.63)\end{array}$ & $\begin{array}{l}27.09 \\
(6.44)\end{array}$ & $\begin{array}{l}27.15 \\
(7.01)\end{array}$ \\
\hline Female & 0.75 & 0.63 & 0.67 & 0.83 & 0.22 & 0.58 \\
\hline \multicolumn{7}{|l|}{ Spoken Languages: } \\
\hline English only & 0.66 & 0.65 & 0.65 & 0.62 & 0.60 & 0.63 \\
\hline French only & 0.11 & 0.14 & 0.12 & 0.16 & 0.16 & 0.14 \\
\hline Bilingual & 0.23 & 0.21 & 0.23 & 0.22 & 0.24 & 0.23 \\
\hline \multicolumn{7}{|l|}{ Province of residence: } \\
\hline Quebec & 0.18 & 0.22 & 0.23 & 0.27 & 0.27 & 0.24 \\
\hline Ontario & 0.54 & 0.53 & 0.41 & 0.34 & 0.39 & 0.43 \\
\hline Manitoba, Saskatchewan & 0.03 & 0.04 & 0.05 & 0.09 & 0.06 & 0.05 \\
\hline Alberta & 0.11 & 0.09 & 0.14 & 0.10 & 0.14 & 0.12 \\
\hline $\mathrm{BC}$ & 0.10 & 0.08 & 0.14 & 0.14 & 0.08 & 0.11 \\
\hline Other provinces & 0.04 & 0.04 & 0.03 & 0.07 & 0.06 & 0.05 \\
\hline \multicolumn{7}{|l|}{ Father's education: } \\
\hline Elementary & 0.25 & 0.26 & 0.27 & 0.27 & 0.25 & 0.26 \\
\hline Secondary & 0.43 & 0.43 & 0.43 & 0.44 & 0.44 & 0.43 \\
\hline Trade & 0.05 & 0.04 & 0.05 & 0.05 & 0.06 & 0.05 \\
\hline College & 0.09 & 0.12 & 0.09 & 0.10 & 0.10 & 0.10 \\
\hline University & 0.18 & 0.15 & 0.15 & 0.14 & 0.15 & 0.15 \\
\hline \multicolumn{7}{|l|}{ Mother's education: } \\
\hline Elementary & 0.19 & 0.20 & 0.21 & 0.19 & 0.20 & 0.20 \\
\hline Secondary & 0.48 & 0.47 & 0.53 & 0.51 & 0.51 & 0.51 \\
\hline Trade & 0.03 & 0.03 & 0.03 & 0.04 & 0.03 & 0.03 \\
\hline College & 0.16 & 0.19 & 0.14 & 0.14 & 0.14 & 0.15 \\
\hline University & 0.15 & 0.12 & 0.09 & 0.12 & 0.12 & 0.12 \\
\hline Was working prior to college & 0.44 & 0.42 & 0.39 & 0.46 & 0.44 & 0.43 \\
\hline \multicolumn{7}{|l|}{ Level of education before: } \\
\hline Secondary-Trade & 0.86 & 0.88 & 0.89 & 0.77 & 0.85 & 0.85 \\
\hline College & 0.06 & 0.07 & 0.06 & 0.15 & 0.10 & 0.09 \\
\hline University & 0.08 & 0.04 & 0.05 & 0.08 & 0.05 & 0.06 \\
\hline Used student loans & 0.42 & 0.47 & 0.38 & 0.50 & 0.44 & 0.44 \\
\hline \multicolumn{7}{|l|}{ Number of observations: } \\
\hline 1990 & 645 & 420 & 1,168 & 1,043 & 1,943 & 5,219 \\
\hline 1995 & 1,016 & 650 & 1,594 & 1,015 & 3,287 & 7,562 \\
\hline Total & 1,661 & 1,070 & 2,762 & 2,058 & 5,230 & 12,781 \\
\hline
\end{tabular}

Note: Figures in parentheses are standard-deviations 


\section{Empirical Results}

All results are reported in Tables 5 through 8 (see appendix). Our analysis will primarily focus on the selection equations, while we will also comment on wage equations.

\section{Earnings Equations}

The estimated selection-corrected earnings equations using Lee's procedure (Lee, 1983) are reported in Table 5. The primary purpose of estimating earning equations is to obtain predicted self-selection corrected log annual earning estimates, which are thereafter included as covariates in the conditional multinomial logit model. The estimated coefficient on the correction term reflect the extent of selfselection in each field of study (i.e. the differences in earnings between the group of students who chose a given field of study and a group of students who would be assigned at random to the same field).

Results provide evidence for self-selection in three fields of study "Social Sciences," "Health" and "Sciences." The coefficient on the correction term is not significantly different from zero in the two remaining fields. Students who choose "Health" or "Sciences" on average earn higher wages as compared to students drawn at random with identical observed characteristics and assigned to the same fields of study (positive coefficient on the correction term). In contrast, students who choose "Social Sciences" on average earn lower wages than identical individuals selected randomly and assigned to these fields (negative coefficient on the correction term).

Since we are using data from recent young graduates, the signs of the coefficients on age and age squared are not necessarily as one may expect (positive coefficient on age and negative coefficient on age squared, and both coefficients are significant). This is, for example, the case when estimating earnings equation in "Health." An interesting result from Table 4 is the increase in the elasticity of annual earnings with respect to weekly worked hours for 1995 graduates in all fields of study, which 
reflects a significant increase in hourly wages paid to 1995 graduates. This is the case particularly for graduates in "Education, Fine Art and Humanities" and "Business and Commerce," but also for "Health" graduates despite the fact that their mean annual earnings decreased by about $8 \%$.

Female graduates earn less than male graduates in "Social Sciences," "Business and Commerce" and "Health." This gap is about $28 \%$ in "Health," while, on the other hand, female graduates in "Sciences" earn more than male graduates in "Sciences" $\left(+13 \%\right.$ in 1992). ${ }^{9}$ Given knowledge that females represent $83 \%$ of graduates in "Health" versus $22 \%$ in "Sciences", it seems like if those gaps aim at attracting males toward "Health" and females toward "Sciences." However, the female advantage in "Sciences" was significantly reduced in 1997 (minus 9.39 points) as opposed to an insignificant variation between 1992 and 1997 in the gap between the two genders in the four other fields of study.

Concerning the effect of the spoken languages on the earnings level, results are contrasted. Graduates who speak only English were disadvantaged only in "Education, Fine Art and Humanities," but significantly advantaged in "Social Sciences." On the other hand, speaking only French is a drawback for "Business and Commerce" and "Health" graduates. We notice also that there is no significant change in the effect of spoken languages when comparing earnings of 1990 graduates to those of 1995 graduates.

In order to examine the effect of self-selection correction on earnings equations estimates, we present estimated uncorrected field-specific earnings equations in Table 6. Obviously, there is no significant effect in fields of study where students do not self-select themselves (i.e. "Education, Fine Art and Humanities" and "Business and Commerce"). The more surprising results concern the gap between 1990 male and female graduates in "Health" and "Sciences." Indeed, this gap increases from 6.35\% to $27.96 \%$ in favour of males in "Health", while, on the other hand, it goes from $8.70 \%$ in favour of males

\footnotetext{
${ }^{9}$ These results obtained after controlling for observed characteristics and self-selection cannot be compared with those in Table 2.
} 
to $13.24 \%$ in favour of females in "Sciences" when self-selection is adjusted. Similarly, log weekly hours coefficient in uncorrected estimates is overestimated in "Sciences" and underestimated in "Health" as compared to selection-adjusted estimates. Concerning the coefficients on provinces, unadjusted estimates in "Health" suggest that only the coefficient on Ontario is significantly different from zero $(+14 \%)$, while adjusted estimates reflect acceptable dispersion across provinces.

\section{Determinants of Choice of Field of Study}

The core results of our study are the conditional logit estimates, which are reported in Table 7. Estimated coefficients specific to each field should be interpreted as variations relative to field "Education, Fine Arts and Humanities." Results from the conditional logit model are not easy to interpret directly. Yet, it is interesting to examine the estimated coefficient on log annual earnings. In fact, since this coefficient is the same across choices, its sign and magnitude determine the direction and magnitude of the effect of earnings on the probability of choosing each field of study. ${ }^{10}$ The estimated coefficient on earnings is positive and statistically significant at the level 1 percent, a fact which supports the hypothesis that predicted earnings after graduation influence the choice of a field of study. Yet, the magnitude of the weight put on earnings varies according to work experience at the time the choice is made and gender. Indeed, our results indicate that students who were employed prior to starting college put an extra weight on earnings $(+0.59)$ when choosing their fields of study as compared

to students who were not working. By this behaviour, former students tend to compensate the opportunity cost associated with leaving jobs they held prior to college. Conversely, female graduates put less weight on earnings when choosing their field of study (-0.29) as compared to male graduates.

\footnotetext{
${ }^{10}$ From Equation (11) it is easy to show that $\partial P_{m} / \partial y_{m}=\alpha P_{m}\left(1-P_{m}\right)$ and $\partial P_{m} / \partial y_{j}=-\alpha P_{m} P_{j}, m \neq j$
} 
Montmarquette, Cannings and Mahseredjian (2002) find the same results on the basis of American data. ${ }^{11}$ This result also agrees with the fact that women are in a majority in low-wage fields of study.

When annual earnings included in the conditional logit are not adjusted of self-selection bias, the weight put on earnings slightly increases for male students who were not working prior to college (going from 1.00 to 1.19 ), while it remains comparable for male students who were working (increasing from 1.60 to 1.68) and for female graduates (decreasing form 0.72 to 0.64 ). Consequently, our results seem to be generally robust to self-selection adjustment.

For easier interpretation, results from the conditional multinomial logit model are converted into marginal effects (cf. Table 8). Results should be interpreted as the effect that a unit change in a covariate has on the probability of choosing a specific field of study over other fields of study, holding all else constant. For dummy variables, the marginal effect measures the discrete change in the probability between 0 and 1.

An important point that is made obvious by Table 8 is that most of the marginal effects are significant at the level 1 percent. In concordance with descriptive statistics, women are unlikely to select "Sciences." They rather are likely to select "Health," "Business and Commerce" or "Education, Fine Arts and Humanities.” Incidentally, spoken languages do not seem to influence much the choices of students.

Concerning the effects of parents' education levels, we notice that the likelihood of choosing "Education, Fine Arts and Humanities" increases when parents received university education. In addition, a student is unlikely to choose "Business and Commerce" when his or her mother received university education. Also, when parents received college education, it increases the likelihood of choosing "Social Sciences." There are, however, contrasting effects on the likelihood of choosing "Health" or "Sciences" when the education level of parents is trade of vocational training. Fathers

\footnotetext{
${ }^{11}$ Our results can not be directly compared with those of Montmarquette, Cannings and Mahseredjian (2002), since we use log of selection adjusted earnings in the conditional logit, whereas the former authors use unadjusted
} 
favour studies in "Sciences" while mothers favour studies in "Health." Concerning the effects of work experience, results suggest that being employed prior to starting college favour the choice of studies in "Education, Fine Arts and Humanities," while it slightly reduces the probability of choosing "Business and Commerce." On another hand, students who are supported by student loans are more likely to select "Health" or "Social Sciences." This result might be of relevance for policies aimed at attracting more young people towards these fields. In contrast, results suggest that students who do not use student loans mainly favour "Business and Commerce" and to a lesser extent "Education, Fine Arts and Humanities." The latter fields (mainly fine art and business) are generally popular among students from affluent families, who actually are able to support their children financially.

Once again, all the marginal effects of predicted earnings after graduation are highly significant. Increasing the log of earnings in a specific field of study (while holding all else constant) significantly increases the probability of choosing this field and reduces the probability of choosing any of the competing fields of study. For instance, if log of earnings in "Sciences" increase by one unit, the probability of choosing this field is expected to increase by 0.19 . Of course, this increase is to the detriment of the four other fields of study. Indeed, the probabilities of choosing "Education, Fine Arts and Humanities," "Social Sciences," "Business and Commerce" or "Health" are expected to decrease by $0.043,0.033,0.071$ and 0.043 respectively following the increase in the log of earnings in "Sciences." In concordance with results above, students who were working prior to starting college are more sensitive to earning variations as compared to those who were not working. Conversely, women are less influenced by these variations as compared to men. In addition, the probability of choosing "Business and Commerce" is the most sensitive to log annual earning variations, both positively and negatively. Indeed, when log annual earnings increase in a specific field of study, the effect on the probability of choosing the same field is the largest in "Business and Commerce." Moreover, the probability of choosing "Business and Commerce" is the most affected when log annual earnings vary in other fields

earnings. Moreover, these authors control for the probability of success in each program of study. 
of study. "Sciences" is the second most sensitive field to earning changes. On the other end of spectrum, "Social Sciences" is the least influenced by log annual earning variations. The latter result agrees with the fact that the share of "Social Sciences" increased despite the decrease in earnings of graduates in this field of study.

Lastly, a most interesting exercise is to examine whether estimated marginal effects of earnings in Table 8 are consistent with observed changes in Tables 1 and 2. For instance, given the variations in earnings in the five fields of study (Table 2), the probability of choosing "Health" should decrease by 2.31 points, ceteris paribus, versus 2.92 points as actual variation. Similarly, the probability of choosing "Sciences" should decrease by 3.51 points, ceteris paribus, while the real variation was +2.03 points. In "Education, Fine Arts, Humanities," our results predict a decrease of 0.96 points in the probability of choosing this field, a variation that is close to that observed (-0.54 points). The predicted changes in the probabilities of choosing "Business and Commerce" and "Social Sciences" following the changes in earnings have different signs than those really observed. This reflects the mis-match in timing between expected earnings and enrolment decisions in these fields as shown in Tables 1 and 2. Obviously, earnings are not the unique determinant in the enrolment decisions. Other variables, observed or not, also influence those decisions. In addition, the estimated model is merely a partial equilibrium model. In particular, wages in each program of study are most likely to react to any induced change in the choices of students. Finally, a simplified five-point (fields of study) graph cannot explain the entire story.

\section{Conclusion}

In this paper, we use Canadian data to analyze the determinants of major field choice in community colleges. The structural model combining selection and earnings equations is estimated using data from a sample of 12,781 individuals who successfully completed their programs at Canadian community colleges (CEGEPs in Quebec) in 1990 and 1995. Our results provide a new empirical evidence for the 
view that the choice of a college field of study depends upon anticipated earnings after graduation. In addition, it was found that women are less influenced by earnings as compared to men. One innovation of our study is that we control for work experience prior to starting college. We find that individuals who were employed prior to starting college put more weight on earnings when choosing their fields of study. We also find that the probability of selecting "Business and Commerce" or "Sciences" is relatively the most sensitive to earnings variations. Conversely, students who select "Social Sciences" are least sensitive to monetary motives. The magnitude of the weights put on earnings when choosing a field of study only slightly change if the selection bias is ignored when predicting earnings in each field of study. Finally, the choice of a field of study also significantly depends upon many other variables (gender, parents' education, etc).

As a final point, we should mention that some selection biases still persist in our estimates. On one hand, we focus only on people who choose to carry out studies at community colleges, and so we ignore those who choose other options (entering the labour force or undertaking university studies, for example). On the other hand, we assume that students who select a college field will successfully complete their programs. In fact, some students drop out or fail to complete the requirements of their program. ${ }^{12}$ Unfortunately, data limitation does not make it possible to control for these biases.

\footnotetext{
${ }^{12}$ See Montmarquette, Cannings and Mahseredjian (2002) for a good application of the use of student's perceived probability of success.
} 


\section{References}

Almquist, E. M.; Angrist, S. S. (1970), "Career Salience and Atypicality of Occupational Choice among College Women," Journal of Marriage and the Family, Volume 32, Issue 2 (May, 1970), 242-249.

Angle, J., Wissmann, D. A. (1981), "Gender, College Major, and Earnings," Sociology of Education 1981, Vol. 54 (Jannuary): 25-33.

Berger, M.C. (1988), "Predicted Future Earnings and Choice of College Major," Industrial and Labour Relations Review, 41, 418-429.

Betts, Julian R., Laurel L. McFarland (1995), "Safe Port in a Storm: The Impact of Labor Market Conditions on Community College Enrollments," The Journal of Human Resources, Vol. 30, No. 4. (Autumn, 1995), pp. 741-765.

Blakemore, A. E.; Low, S. A. (1984), "Sex Differences in Occupational Selection: The Case of College Majors," The Review of Economics and Statistics, Volume 66, Issue 1 (Feb., 1984), 157-163.

Bourguignon F., Fournier M., and Gurgand M. (2001), "Selection Bias Correction Based on the Multinomial Logit Model," CREST Working Paper, 2001.

Card, D. (1999), "The Causal Effect of Education on Earnings," In Orley Ashenfelter and David Card, editors, Handbook of labor Economics, Volume 3. Amsterdam: Elsevier Science.

Card, D. (June 2000), "Estimating the Return to Schooling : Progress on Some Persistent Econometric Problems", NBER WORKING PAPERS SERIES, Working Paper no.7769.

Card, D. and Lemieux, T. (2000b), "Dropout and Enrollment Trends in The Post-War Period: What Went Wrong in The 1970s?” NBER WORKING PAPERS SERIES, Working Paper no.7658.

Chapman, D. W. (1981), “A Model of Student College Choice," The Journal of Higher Education, Volume 52, Issue 5 (Sep.-Oct., 1981), 490-505.

Daymont, T.N., Andrisani, P.J. (1984), "Job Preferences, College Major, and the Gender Gap in Earnings," The Journal of Human Resources, Volume 19, Issue 3 (Summer, 1984), 408-428.

David A. Dodge, D. A. and Stager, D. A. A. (1972), "Economic Returns to Graduate Study in Science, Engineering and Business," The Canadian Journal of Economics, Vol. 5, No. 2. (May, 1972), pp. 182-198.

Finnie, R. (1999), "Earnings of University Graduates in Canada by Discipline. Fields of Plenty, Fields of Lean. A Cross-Cohort Longitudinal Analysis of Early Labour Market Outcomes," Applied Research Branch Strategic Policy. Human Resources Development Canada. R-99-13E.a. August 1999.

Fiorito, J.; Dauffenbach, R. C. (1982), "Market and Nonmarket Influences on Curriculum Choice by College Students," Industrial and Labor Relations Review, Volume 36, Issue 1 (Oct., 1982), 88101.

Freeman, Richard B. (1976), "A Cobweb Model of the Supply and Starting Salary of New Engineers," Industrial and Labor Relations Review, Vol. 29, No. 2. (Jan., 1976), pp. 236-248. 
Hearn, J. C. (1980), "Major Choice and the Well-Being of College Men and Women: An Examination from Developmental, Organizational, and Structural Perspectives," Sociology of Education, Volume 53, Issue 3 (Jul., 1980), 164-178.

Kane, T. J. (1994), "College Entry by Blacks since 1970: The Role of College Costs, Family Background, and the Returns to Education," The Journal of Political Economy, Vol. 102, No. 5. (Oct., 1994), pp. 878-911.

Keane, M. and K. Wolpin (1997), "The Career Decisions of Young Men," The Journal of Political Economy, Vol. 105, No. 3. (Jun., 1997), pp. 473-522.

Koch, J. V. (1972), "Student Choice of Undergraduate Major Field of Study and Private Internal Rates of Return," Industrial and Labor Relations Review, Volume 26, Issue 1 (Oct., 1972), 680-685.

Lee, Lung-Fei (1976), "Estimated of Limited Dependent Variables by two Stage Method," Ph.D. Thesis, Department of Economics, University of Rochester, (1976), Chapters 2 and 3.

Lee, Lung-Fei (1978), "Unionism and Wage Rates: A Simultaneous Equations Model with Qualitative and Limited Dependent Variables," International Economic Review, Vol. 19, No. 2. (Jun., 1978), pp. 415-433.

Lee, Lung-Fei (1983), “Generalized Econometric Models with Selectivity,” Econometrica, Vol. 51, No.2 (March, 1983), 507-512.

Lee, L.F.; Maddala, G.S.; Trost, R.P. (1980), "Asymptotic Covariance Matrices of Two-Stage Probit and Two-Stage Tobit Methods for Simultaneous Equations with Selectivity," Econometrica, Vol. 48, No. 2 (Mar., 1980), 491-504.

Litten, L. H. (1982), "Different Strokes in the Applicant Pool: Some Refinements in a Model of Student College Choice," The Journal of Higher Education, Volume 53, Issue 4 (Jul.-Aug., 1982), 383-402.

Maddala, G.S. (1983), "Limited Dependent and Qualitative variables in Econometrics," Cambridge University Press, 1983.

Maxey, J.; Lee J. S.; McLure, G. (1995), “Are Black Students Less Likely to Enroll at their First-Choice College?" The Journal of Blacks in Higher Education, Volume 0, Issue 7 (Spring, 1995), 100-101.

McFadden, D. (1973), "Conditional Logit Analysis of Qualitative Choice Behavior," In Frontiers in Econometrics, Ed. By P. Zarembka. New York : Academic Press, 1973.

Medalia, N. Z. (1968), "Choice of College Major by Contest Mobility," Sociology of Education, Volume 41, Issue 3 (Summer, 1968), 282-290.

Mitchell, T. R.; Kundsen, B. W. (1973), “Instrumentality Theory Predictions of Students' Attitudes toward Business and Their Choice of Business as an Occupation," The Academy of Management Journal, Volume 16, Issue 1 (Mar., 1973), 41-52.

Montmarquette, C., Cannings, K. and Mahseredjian, S. (2002), "How do Young People Choose College Majors?" Economics of Education Review, 21(6), 2002, 543-556.

Montmarquette, C., Mourji F., Mahseredjian, S. (1998), "Les Choix de Filières Universitaires par les Lycéens Marocains: Préférences et Contraintes," L'actualité Economique, Revue d'Analyse Economique, vol. 74, no3, septembre 1998.

OECD (2002). "Education at a Glance: OECD Indicators 2002." Organisation for Economic Cooperation and Development (2002) 
Paglin, M.; Rufolo, A. M. (1990), "Heterogeneous Human Capital, Occupational Choice, and MaleFemale Earnings Differences," Journal of Labor Economics, Volume 8, Issue 1, Part 1 (Jan., 1990), 123-144.

Polachek, S. W. (1978), "Sex Differences in College Major," Industrial and Labor Relations Review, Volume 31, Issue 4 (Jul., 1978), 498-508.

Turner, S. and Bowen, W.G. (1999), "Choice of Major: The Changing (unchanging) Gender Gap," Industrial and Labour Relations Review 52 (2), 289-311.

Vaillancourt, F. (1995), "The Private and Total Returns to Education in Canada, 1985," The Canadian Journal of Economics, Vol. 28, No. 3. (Aug., 1995), pp. 532-554.

Vujicic, M. (2003), “The Nursing Labour Market in Canada, 1980-2000,” Ph.D. dissertation, University of British Columbia, 2003.

Weiss, Y. (1971), "Investment in Graduate Education," The American Economic Review, Volume 61, Issue 5 (Dec., 1971), 833-852.

Wilkinson, B. W. (1966), "Present Value of Lifetime Earnings for Different Occupations," The Journal of Political Economy, Volume 74, Issue 6 (Dec., 1966), 556-572.

Willis, R.J.; Rosen, S. (1979), "Education and Self-Selection," The Journal of Political Economy, Volume 87, Issue 5, Part 2: Education and Income Distribution (Oct., 1979), S7-S36.

Willis, R.J. (1986), "Wage Determinants: A Survey and Reinterpretation of Human Capital Earnings Function," In Orley Ashenfelter and Richard Layard, editors, Handbook of Labor Economics, (North Holland, Amsterdam and New York). 
Table 5

Estimated Selection-Adjusted Earnings Equations

\begin{tabular}{|c|c|c|c|c|c|c|c|c|c|c|}
\hline & \multicolumn{2}{|c|}{$\begin{array}{c}\text { Education, Fine Arts, } \\
\text { Humanities }\end{array}$} & \multicolumn{2}{|c|}{$\begin{array}{c}\text { Social } \\
\text { Sciences }\end{array}$} & \multicolumn{2}{|c|}{$\begin{array}{l}\text { Commerce, } \\
\text { Business }\end{array}$} & \multicolumn{2}{|c|}{ Health } & \multicolumn{2}{|c|}{ Sciences } \\
\hline & Coef. & Std. Err. & Coef. & Std. Err. & Coef. & Std. Err. & Coef. & Std. Err. & Coef. & Std. Err. \\
\hline Constant & $7.7517^{(\mathrm{a})}$ & 0.3230 & $6.0583^{(\mathrm{a})}$ & 0.4775 & $6.7196^{(\mathrm{a})}$ & 0.2535 & $8.7746^{(\mathrm{a})}$ & 0.2802 & $7.9027^{(\mathrm{a})}$ & 0.3564 \\
\hline Age & $0.0281^{(\mathrm{c})}$ & 0.0157 & $0.0431^{(\mathrm{b})}$ & 0.0218 & $0.0674^{(\mathrm{a})}$ & 0.0123 & $-0.0436^{(\mathrm{a})}$ & 0.0161 & $0.0529^{(a)}$ & 0.0132 \\
\hline Age Squared & -0.0003 & 0.0002 & -0.0005 & 0.0003 & $-0.0009^{(a)}$ & 0.0002 & $0.0006^{(\mathrm{b})}$ & 0.0002 & $-0.0007^{(a)}$ & 0.0002 \\
\hline $\begin{array}{l}\text { Log Weekly } \\
\text { Hours }\end{array}$ & $0.4321^{(a)}$ & 0.0520 & $0.6568^{(\mathrm{a})}$ & 0.0804 & $0.5586^{(\mathrm{a})}$ & 0.0462 & $0.7951^{(\mathrm{a})}$ & 0.0524 & $0.3582^{(a)}$ & 0.0522 \\
\hline Female & 0.0105 & 0.0437 & $-0.1196^{(a)}$ & 0.0405 & $-0.1305^{(\mathrm{a})}$ & 0.0249 & $-0.2796^{(a)}$ & 0.0403 & $0.1324^{(\mathrm{b})}$ & 0.0715 \\
\hline Permanent Job & $0.0759^{(\mathrm{b})}$ & 0.0377 & $0.1135^{(\mathrm{b})}$ & 0.0527 & $0.1082^{(a)}$ & 0.0265 & $-0.0930^{(a)}$ & 0.0332 & $0.1742^{(\mathrm{a})}$ & 0.0207 \\
\hline \multicolumn{11}{|l|}{ Spoken Languages } \\
\hline English only & $-0.1181^{(\mathrm{b})}$ & 0.0465 & $0.1618^{(\mathrm{b})}$ & 0.0658 & 0.0121 & 0.0352 & -0.0139 & 0.0382 & -0.0340 & 0.0297 \\
\hline French only & -0.0726 & 0.0636 & -0.0104 & 0.0839 & $-0.0923^{(b)}$ & 0.0386 & $-0.1020^{(a)}$ & 0.0394 & -0.0214 & 0.0280 \\
\hline \multicolumn{11}{|c|}{ Province of Residence } \\
\hline Quebec & 0.0857 & 0.0899 & $0.4472^{(\mathrm{a})}$ & 0.1084 & 0.1169 & 0.0885 & $0.1393^{(b)}$ & 0.0600 & 0.0199 & 0.0449 \\
\hline Ontario & $0.1429^{(\mathrm{c})}$ & 0.0761 & $0.3140^{(a)}$ & 0.0781 & $0.1641^{(\mathrm{b})}$ & 0.0797 & $0.3223^{(a)}$ & 0.0500 & $0.1463^{(a)}$ & 0.0371 \\
\hline $\begin{array}{l}\text { Manitoba, } \\
\text { Saskat. }\end{array}$ & -0.0104 & 0.1097 & 0.1180 & 0.1435 & -0.0109 & 0.0910 & 0.0909 & 0.0572 & 0.0010 & 0.0490 \\
\hline Alberta & -0.1263 & 0.0848 & 0.1480 & 0.0914 & 0.0731 & 0.0840 & $0.2444^{(\mathrm{a})}$ & 0.0559 & $0.1229^{(a)}$ & 0.0394 \\
\hline B.C. & 0.1269 & 0.0853 & $0.2549^{(\mathrm{b})}$ & 0.1005 & $0.2057^{(\mathrm{b})}$ & 0.0860 & $0.2115^{(\mathrm{a})}$ & 0.0553 & $0.2306^{(\mathrm{a})}$ & 0.0447 \\
\hline Year 1997 & $-2.0924^{(\mathrm{a})}$ & 0.4044 & -0.3849 & 0.5372 & $-1.3129^{(a)}$ & 0.3147 & $-1.6196^{(a)}$ & 0.3249 & $-1.3262^{(a)}$ & 0.2729 \\
\hline \multicolumn{11}{|l|}{ Year 1997 x } \\
\hline Age & $0.0347^{(\mathrm{c})}$ & 0.0199 & -0.0286 & 0.0246 & -0.0205 & 0.0150 & $0.0589^{(\mathrm{a})}$ & 0.0172 & 0.0106 & 0.0139 \\
\hline Age Squared & -0.0005 & 0.0003 & 0.0004 & 0.0004 & 0.0003 & 0.0002 & $-0.0008^{(a)}$ & 0.0003 & -0.0002 & 0.0002 \\
\hline $\begin{array}{l}\text { Log Weekly } \\
\text { Hours }\end{array}$ & $0.4119^{(\mathrm{a})}$ & 0.0636 & $0.3218^{(a)}$ & 0.0972 & $0.4566^{(\mathrm{a})}$ & 0.0556 & $0.1933^{(a)}$ & 0.0492 & $0.3424^{(a)}$ & 0.0466 \\
\hline Female & -0.0604 & 0.0431 & 0.0509 & 0.0508 & -0.0107 & 0.0284 & 0.0032 & 0.0380 & $-0.0939^{(a)}$ & 0.0241 \\
\hline Permanent Job & -0.0733 & 0.0467 & -0.1046 & 0.0637 & $-0.0606^{(\mathrm{c})}$ & 0.0357 & 0.0516 & 0.0418 & $-0.0944^{(a)}$ & 0.0281 \\
\hline English only & 0.0597 & 0.0551 & -0.1047 & 0.0764 & 0.0071 & 0.0421 & 0.0225 & 0.0470 & 0.0358 & 0.0350 \\
\hline French only & 0.0902 & 0.0816 & 0.1494 & 0.1060 & 0.0238 & 0.0527 & 0.0169 & 0.0571 & 0.0125 & 0.0366 \\
\hline
\end{tabular}


Table 5 (Continued)

\begin{tabular}{|c|c|c|c|c|c|c|c|c|c|c|}
\hline \multirow[b]{2}{*}{ Year 1997 x } & \multicolumn{2}{|c|}{$\begin{array}{c}\text { Education, Fine Arts, } \\
\text { Humanities }\end{array}$} & \multicolumn{2}{|c|}{$\begin{array}{c}\text { Social } \\
\text { Sciences }\end{array}$} & \multicolumn{2}{|c|}{$\begin{array}{l}\text { Commerce, } \\
\text { Business }\end{array}$} & \multicolumn{2}{|c|}{ Health } & \multicolumn{2}{|c|}{ Sciences } \\
\hline & & & & & & & & & & \\
\hline Quebec & 0.0501 & 0.1126 & -0.2492 & 0.1567 & 0.0556 & 0.1009 & $-0.1450^{(\mathrm{c})}$ & 0.0822 & $0.1147^{(\mathrm{b})}$ & 0.0571 \\
\hline Ontario & 0.1064 & 0.0926 & -0.0810 & 0.1323 & 0.0503 & 0.0907 & $-0.2281^{(a)}$ & 0.0653 & $0.0936^{(\mathrm{b})}$ & 0.0450 \\
\hline $\begin{array}{l}\text { Manitoba, } \\
\text { Saskat. }\end{array}$ & 0.0955 & 0.1411 & -0.1330 & 0.1886 & 0.0655 & 0.1067 & $-0.2406^{(a)}$ & 0.0819 & 0.0966 & 0.0599 \\
\hline Alberta & $0.2583^{(\mathrm{b})}$ & 0.1054 & -0.0617 & 0.1384 & 0.1092 & 0.0945 & $-0.1787^{(b)}$ & 0.0754 & 0.0551 & 0.0495 \\
\hline B.C. & $0.2372^{(b)}$ & 0.1070 & -0.0346 & 0.1470 & 0.1006 & 0.0952 & -0.0152 & 0.0757 & $0.1384^{(\mathrm{b})}$ & 0.0551 \\
\hline Correction term & -0.0311 & 0.0705 & $-0.2373^{(\mathrm{b})}$ & 0.0948 & 0.0199 & 0.0471 & $0.3778^{(\mathrm{a})}$ & 0.0533 & $0.2346^{(\mathrm{a})}$ & 0.0740 \\
\hline Residual S.E. & 0.3631 & & 0.4203 & & 0.3347 & & 0.4606 & & 0.3932 & \\
\hline Adj. R-squared & 0.3298 & & 0.3580 & & 0.3998 & & 0.4194 & & 0.3147 & \\
\hline \# observations & 1,661 & & 1,070 & & 2,762 & & 2,058 & & 5,230 & \\
\hline
\end{tabular}

Notes: (a), (b) and (c): significant at the level 1, 5 and 10 percent (Two-tailed test). Data are weighted. 
Table 6

Estimated Unadjusted Earnings Equations

\begin{tabular}{|c|c|c|c|c|c|c|c|c|c|c|}
\hline & \multicolumn{2}{|c|}{$\begin{array}{c}\text { Education, Fine Arts, } \\
\text { Humanities }\end{array}$} & \multicolumn{2}{|c|}{$\begin{array}{c}\text { Social } \\
\text { Sciences }\end{array}$} & \multicolumn{2}{|c|}{$\begin{array}{l}\text { Commerce, } \\
\text { Business }\end{array}$} & \multicolumn{2}{|c|}{ Health } & \multicolumn{2}{|c|}{ Sciences } \\
\hline & Coef. & Std. Err. & Coef. & Std. Err. & Coef. & Std. Err. & Coef. & Std. Err. & Coef. & Std. Err. \\
\hline Constant & $7.7701^{(a)}$ & 0.3202 & $6.3507^{(a)}$ & 0.4642 & $6.6952^{(a)}$ & 0.2466 & $8.0134^{(a)}$ & 0.2566 & $7.0491^{(\mathrm{a})}$ & 0.2339 \\
\hline Age & $0.0300^{(\mathrm{b})}$ & 0.0151 & $0.0532^{(\mathrm{b})}$ & 0.0214 & $0.0652^{(\mathrm{a})}$ & 0.0111 & 0.0178 & 0.0136 & $0.0715^{(\mathrm{a})}$ & 0.0120 \\
\hline Age Squared & -0.0003 & 0.0002 & $-0.0006^{(\mathrm{b})}$ & 0.0003 & $-0.0008^{(a)}$ & 0.0002 & -0.0002 & 0.0002 & $-0.0010^{(a)}$ & 0.0002 \\
\hline $\begin{array}{l}\text { Log Weekly } \\
\text { Hours }\end{array}$ & $0.4324^{(\mathrm{a})}$ & 0.0520 & $0.6463^{(a)}$ & 0.0808 & (a) & 0.0440 & $0.5605^{(\mathrm{a})}$ & 0.0381 & $.4708^{(\mathrm{a})}$ & 0.0382 \\
\hline Female & -0.0020 & 0.0334 & $-0.1267^{(a)}$ & 0.0406 & $-0.1251^{(a)}$ & 0.0214 & $-0.0635^{(\mathrm{b})}$ & 0.0281 & $-0.0870^{(a)}$ & 0.0188 \\
\hline Permanent Job & $0.0804^{(\mathrm{b})}$ & 0.0362 & $0.1136^{(\mathrm{b})}$ & 0.0531 & $0.1082^{(\mathrm{a})}$ & 0.0264 & -0.0007 & 0.0309 & $0.1567^{(\mathrm{a})}$ & 0.0198 \\
\hline \multicolumn{11}{|l|}{ Spoken Languages } \\
\hline English only & $-0.1142^{(b)}$ & 0.0456 & $0.1603^{(\mathrm{b})}$ & 0.0660 & 0.0127 & 0.0352 & -0.0263 & 0.0386 & -0.0178 & 0.0294 \\
\hline French only & -0.0698 & 0.0633 & 0.0086 & 0.0843 & $-0.0938^{(b)}$ & 0.0384 & $-0.0803^{(b)}$ & 0.0388 & -0.0125 & 0.0274 \\
\hline \multicolumn{11}{|c|}{ Province of Residence } \\
\hline Quebec & 0.0901 & 0.0894 & $0.4952^{(\mathrm{a})}$ & 0.1071 & 0.1287 & 0.0840 & -0.0020 & 0.0552 & 0.0551 & 0.0431 \\
\hline Ontario & $0.1345^{(\mathrm{c})}$ & 0.0737 & $0.3290^{(\mathrm{a})}$ & 0.0779 & $0.1755^{(\mathrm{b})}$ & 0.0750 & $0.1418^{(a)}$ & 0.0411 & $0.1121^{(\mathrm{a})}$ & 0.0352 \\
\hline $\begin{array}{l}\text { Manitoba, } \\
\text { Saskat. }\end{array}$ & -1 & 4 & 90 & 0.1390 & 1 & 0.0 & 381 & 7 & 5 & 30 \\
\hline Alberta & -0.1274 & 0.0848 & $0.1814^{(\mathrm{b})}$ & 0.0908 & 0.0864 & 0.0778 & 0.0730 & 0.0494 & $0.1084^{(\mathrm{a})}$ & 0.0387 \\
\hline B.C. & 0.1228 & 0.0848 & $0.3114^{(\mathrm{a})}$ & 0.0984 & $0.2202^{(a)}$ & 0.0787 & 0.0546 & 0.0491 & $0.1835^{(a)}$ & 0.0420 \\
\hline Year 1997 & $-2.0754^{(\mathrm{a})}$ & 0.4039 & -0.4772 & 0.5367 & $-1.3271^{(\mathrm{a})}$ & 0.3132 & $-1.1843^{(\mathrm{a})}$ & 0.3174 & $-1.3178^{(a)}$ & 0.2749 \\
\hline \multicolumn{11}{|l|}{ Year $1997 \mathrm{x}$} \\
\hline Age & $0.0332^{(\mathrm{c})}$ & 0.0198 & -0.0288 & 0.0246 & -0.0186 & 0.0144 & 0.0204 & 0.0163 & 0.0021 & 0.0137 \\
\hline Age Squared & -0.0004 & 0.0003 & 0.0004 & 0.0004 & 0.0003 & 0.0002 & -0.0002 & 0.0002 & 0.0000 & 0.0002 \\
\hline $\begin{array}{l}\text { Log Weekly } \\
\text { Hours }\end{array}$ & $0.4136^{(\mathrm{a})}$ & 0.0 & $0.3711^{(\mathrm{a})}$ & 0 & $0.4549^{(\mathrm{a})}$ & 5 & $0.2093^{(a)}$ & 3 & $0.3711^{(\mathrm{a})}$ & 0.0463 \\
\hline Female & -0.0607 & 0.0431 & 0.0364 & 0.0505 & -0.0113 & 0.0283 & 0.0123 & 0.0403 & $-0.0764^{(a)}$ & 0.0240 \\
\hline Permanent Job & -0.0751 & 0.0465 & -0.0709 & 0.0625 & $-0.0596^{(\mathrm{c})}$ & 0.0354 & -0.0102 & 0.0415 & $-0.0619^{(b)}$ & 0.0260 \\
\hline English only & 0.0553 & 0.0544 & -0.1211 & 0.0763 & 0.0061 & 0.0420 & 0.0437 & 0.0477 & 0.0050 & 0.0338 \\
\hline French only & 0.0875 & 0.0814 & 0.0881 & 0.1039 & 0.0226 & 0.0526 & -0.0175 & 0.0571 & 0.0083 & 0.0359 \\
\hline
\end{tabular}


Table 6 (Continued)

\begin{tabular}{|c|c|c|c|c|c|c|c|c|c|c|}
\hline \multirow{2}{*}{ Year 1997 x } & \multicolumn{2}{|c|}{$\begin{array}{c}\text { Education, Fine Arts, } \\
\text { Humanities }\end{array}$} & \multicolumn{2}{|c|}{$\begin{array}{c}\text { Social } \\
\text { Sciences }\end{array}$} & \multicolumn{2}{|c|}{$\begin{array}{l}\text { Commerce, } \\
\text { Business }\end{array}$} & \multicolumn{2}{|c|}{ Health } & \multicolumn{2}{|c|}{ Sciences } \\
\hline & & & & & & & & & & \\
\hline Quebec & 0.0514 & 0.1125 & $-0.3713^{(b)}$ & 0.1500 & 0.0463 & 0.0984 & -0.0126 & 0.0798 & 0.0642 & 0.0540 \\
\hline Ontario & 0.1108 & 0.0920 & $-0.2322^{(\mathrm{c})}$ & 0.1187 & 0.0400 & 0.0872 & $-0.1401^{(b)}$ & 0.0634 & $0.0782^{(\mathrm{c})}$ & 0.0441 \\
\hline $\begin{array}{l}\text { Manitoba, } \\
\text { Saskat. }\end{array}$ & 0.1023 & 0.1401 & $-0.3026^{(\mathrm{c})}$ & 0.1779 & 0.0535 & 0.1028 & -0.0967 & 0.0767 & 0.0906 & 0.0591 \\
\hline Alberta & $0.2557^{(\mathrm{b})}$ & 0.1053 & -0.1427 & 0.1357 & 0.0991 & 0.0914 & -0.1131 & 0.0753 & 0.0504 & 0.0487 \\
\hline B.C. & $0.2431^{(b)}$ & 0.1063 & -0.1576 & 0.1402 & 0.0907 & 0.0922 & $0.1354^{(\mathrm{c})}$ & 0.0719 & $0.1032^{(\mathrm{c})}$ & 0.0535 \\
\hline Residual S.E. & 0.3621 & & 0.3628 & & 0.3341 & & 0.3324 & & 0.3453 & \\
\hline Adj. R-squared & 0.3294 & & 0.3559 & & 0.4002 & & 0.4048 & & 0.3140 & \\
\hline \# observations & 1,661 & & 1,070 & & 2,762 & & 2,058 & & 5,230 & \\
\hline
\end{tabular}

Notes: (a), (b) and (c): significant at the level 1, 5 and 10 percent (Two-tailed test). Data are weighted. 
Table 7

Estimated Conditional Logit using Selection-Adjusted Earnings (Relative to "Education, Fine Arts and Humanities")

\begin{tabular}{|c|c|c|c|c|c|c|c|c|}
\hline & \multicolumn{2}{|c|}{ Social Sciences } & \multicolumn{2}{|c|}{ Commerce, Business } & \multicolumn{2}{|c|}{ Health } & \multicolumn{2}{|c|}{ Sciences } \\
\hline & Coef. & Std. Err. & Coef. & Std. Err. & Coef. & Std. Err. & Coef. & Std. Err. \\
\hline Constant & $-1.2917^{(\mathrm{a})}$ & 0.0928 & $0.1814^{(\mathrm{b})}$ & 0.0817 & $-1.7587^{(\mathrm{a})}$ & 0.0893 & $0.8015^{(\mathrm{a})}$ & 0.0816 \\
\hline Age & $0.0420^{(a)}$ & 0.0020 & $0.0059^{(a)}$ & 0.0018 & $0.0454^{(\mathrm{a})}$ & 0.0019 & $0.0358^{(a)}$ & 0.0019 \\
\hline Female & $-0.4807^{(\mathrm{a})}$ & 0.0330 & $-0.2873^{(a)}$ & 0.0263 & $0.5070^{(\mathrm{a})}$ & 0.0447 & $-2.2560^{(a)}$ & 0.0311 \\
\hline \multicolumn{9}{|l|}{ Spoken Languages: } \\
\hline English Only & -0.0082 & 0.0380 & 0.0008 & 0.0309 & 0.0443 & 0.0342 & $-0.0661^{(\mathrm{b})}$ & 0.0321 \\
\hline French Only & -0.0222 & 0.0530 & $-0.1234^{(\mathrm{a})}$ & 0.0444 & $0.1087^{(\mathrm{b})}$ & 0.0465 & 0.0309 & 0.0449 \\
\hline \multicolumn{9}{|l|}{ Father's Education } \\
\hline Secondary & 0.0327 & 0.0373 & $-0.1248^{(a)}$ & 0.0310 & -0.0104 & 0.0331 & 0.0015 & 0.0328 \\
\hline Trade, Vocational Training & $-0.1378^{(\mathrm{b})}$ & 0.0696 & $-0.0948^{(\mathrm{c})}$ & 0.0552 & -0.0578 & 0.0599 & $0.2122^{(\mathrm{a})}$ & 0.0568 \\
\hline College & $0.3285^{\text {(a) }}$ & 0.0508 & 0.0144 & 0.0440 & $0.1651^{\text {(a) }}$ & 0.0473 & $0.1815^{\text {(a) }}$ & 0.0461 \\
\hline University & $-0.1462^{(a)}$ & 0.0479 & $-0.1130^{(\mathrm{a})}$ & 0.0395 & $-0.1508^{(a)}$ & 0.0429 & $-0.2000^{(a)}$ & 0.0416 \\
\hline \multicolumn{9}{|l|}{ Mother's Education } \\
\hline Secondary & -0.0198 & 0.0405 & $0.0595^{(\mathrm{c})}$ & 0.0336 & $0.1142^{(\mathrm{a})}$ & 0.0364 & $0.0760^{(\mathrm{b})}$ & 0.0355 \\
\hline Trade, Vocational Training & 0.0191 & 0.0877 & $-0.1940^{(\mathrm{a})}$ & 0.0728 & $0.1351^{(\mathrm{c})}$ & 0.0749 & $-0.2864^{(a)}$ & 0.0766 \\
\hline College & $0.2287^{(a)}$ & 0.0482 & $-0.1715^{(\mathrm{a})}$ & 0.0411 & 0.0262 & 0.0447 & $-0.0831^{(\mathrm{c})}$ & 0.0436 \\
\hline University & $-0.1230^{(\mathrm{b})}$ & 0.0537 & $-0.6085^{(\mathrm{a})}$ & 0.0457 & -0.0250 & 0.0481 & $-0.1921^{(\mathrm{a})}$ & 0.0462 \\
\hline \multicolumn{9}{|l|}{ Province of Residence ${ }^{14}$} \\
\hline Quebec & $0.2702^{(\mathrm{a})}$ & 0.0738 & $0.9853^{(\mathrm{a})}$ & 0.0656 & $0.2236^{(\mathrm{a})}$ & 0.0626 & $0.3497^{(\mathrm{a})}$ & 0.0615 \\
\hline Ontario & 0.0135 & 0.0594 & $0.3720^{(a)}$ & 0.0550 & $-0.6468^{(a)}$ & 0.0499 & $-0.4610^{(a)}$ & 0.0496 \\
\hline Manitoba, Saskat. & $0.1737^{(\mathrm{b})}$ & 0.0861 & $1.1084^{(a)}$ & 0.0737 & $0.7297^{(\mathrm{a})}$ & 0.0678 & $0.4003^{(a)}$ & 0.0702 \\
\hline Alberta & $-0.3737^{(\mathrm{a})}$ & 0.0703 & $0.7257^{(\mathrm{a})}$ & 0.0613 & $-0.5778^{(\mathrm{a})}$ & 0.0579 & $-0.1798^{(\mathrm{a})}$ & 0.0571 \\
\hline B.C. & -0.0180 & 0.0715 & $0.9701^{\text {(a) }}$ & 0.0624 & -0.0034 & 0.0585 & $-0.4210^{(\mathrm{a})}$ & 0.0603 \\
\hline Was Working prior to College & $-0.2706^{(\mathrm{a})}$ & 0.0301 & $-0.3025^{(\mathrm{a})}$ & 0.0236 & $-0.2719^{(a)}$ & 0.0400 & $-0.2552^{(a)}$ & 0.0284 \\
\hline \multicolumn{9}{|c|}{ Level of Education before Enrolment } \\
\hline College & -0.0017 & 0.0510 & -0.0598 & 0.0446 & $0.7187^{(\mathrm{a})}$ & 0.0419 & $0.4208^{(\mathrm{a})}$ & 0.0433 \\
\hline University & $-0.7135^{(\mathrm{a})}$ & 0.0583 & $-0.2948^{(\mathrm{a})}$ & 0.0453 & 0.0355 & 0.0446 & $-0.3056^{(\mathrm{a})}$ & 0.0473 \\
\hline Used Student Loans & $0.2803^{(\mathrm{a})}$ & 0.0260 & $-0.1704^{(\mathrm{a})}$ & 0.0218 & $0.2715^{(\mathrm{a})}$ & 0.0236 & $0.0657^{(\mathrm{a})}$ & 0.0227 \\
\hline
\end{tabular}

${ }^{14}$ Province of residence twelve months prior to starting college 
Table 7 (Continued)

\begin{tabular}{|c|c|c|c|c|c|c|c|c|}
\hline & \multicolumn{2}{|c|}{$\begin{array}{c}\text { Social } \\
\text { Sciences }\end{array}$} & \multicolumn{2}{|c|}{$\begin{array}{l}\text { Commerce, } \\
\text { Business }\end{array}$} & \multicolumn{2}{|c|}{ Health } & \multicolumn{2}{|c|}{ Sciences } \\
\hline & Coef. & Std. Err. & Coef. & Std. Err. & Coef. & Std. Err. & Coef. & Std. Err. \\
\hline Log Annual Earnings & $1.0099^{(\mathrm{a})}$ & 0.1032 & & & & & & \\
\hline \multicolumn{9}{|l|}{ Log Annual Earnings $\mathrm{x}$} \\
\hline Working prior to starting college & $0.5858^{(a)}$ & 0.0999 & & & & & & \\
\hline Female & $-0.2872^{(a)}$ & 0.1085 & & & & & & \\
\hline Mean Log Likelihood & -1.4014 & & & & & & & \\
\hline Pseudo R-squared & 0.1024 & & & & & & & \\
\hline Number of observations & 12,781 & & & & & & & \\
\hline
\end{tabular}


Table 8

Marginal Effects of Covariates on the Probability of Choosing Each Field of Study

\begin{tabular}{|c|c|c|c|c|c|c|c|c|c|c|}
\hline & \multicolumn{2}{|c|}{$\begin{array}{c}\text { Education, Fine Arts, } \\
\text { Humanities }\end{array}$} & \multicolumn{2}{|c|}{$\begin{array}{c}\text { Social } \\
\text { Sciences }\end{array}$} & \multicolumn{2}{|c|}{$\begin{array}{l}\text { Commerce, } \\
\text { Business }\end{array}$} & \multicolumn{2}{|c|}{ Health } & \multicolumn{2}{|c|}{ Sciences } \\
\hline & Coef. & Std. Err. & Coef. & Std. Err. & Coef. & Std. Err. & Coef. & Std. Err. & Coef. & Std. Err. \\
\hline Age & $-0.0040^{(a)}$ & 0.0002 & $0.0024^{(\mathrm{a})}$ & 0.0002 & $-0.0050^{(a)}$ & 0.0003 & $0.0037^{(\mathrm{a})}$ & 0.0002 & $0.0030^{(\mathrm{a})}$ & 0.0003 \\
\hline Female & $0.1048^{(\mathrm{a})}$ & 0.0033 & $0.0278^{(\mathrm{a})}$ & 0.0021 & $0.1058^{(\mathrm{a})}$ & 0.0034 & $0.1805^{(\mathrm{a})}$ & 0.0037 & $-0.4189^{(a)}$ & 0.0031 \\
\hline \multicolumn{11}{|l|}{ Spoken languages: } \\
\hline English Only & 0.0017 & 0.0037 & 0.0002 & 0.0035 & 0.0030 & 0.0047 & $0.0092^{(\mathrm{b})}$ & 0.0039 & $-0.0141^{(\mathrm{a})}$ & 0.0047 \\
\hline French Only & 0.0015 & 0.0054 & -0.0017 & 0.0047 & $-0.0307^{(a)}$ & 0.0059 & $0.0209^{(a)}$ & 0.0052 & $0.0101^{(\mathrm{c})}$ & 0.0059 \\
\hline \multicolumn{11}{|l|}{ Father's education } \\
\hline Secondary & 0.0054 & 0.0038 & $0.0085^{(b)}$ & 0.0034 & $-0.0259^{(a)}$ & 0.0045 & 0.0037 & 0.0036 & $0.0084^{(\mathrm{c})}$ & 0.0046 \\
\hline Trade, Vocational Training & -0.0011 & 0.0067 & $-0.0177^{(\mathrm{a})}$ & 0.0058 & $-0.0271^{(\mathrm{a})}$ & 0.0075 & $-0.0107^{(\mathrm{c})}$ & 0.0062 & $0.0566^{(a)}$ & 0.0086 \\
\hline College & $-0.0201^{(a)}$ & 0.0049 & $0.0288^{(a)}$ & 0.0052 & $-0.0298^{(\mathrm{a})}$ & 0.0060 & 0.0068 & 0.0053 & $0.0143^{(\mathrm{b})}$ & 0.0066 \\
\hline University & $0.0220^{(\mathrm{a})}$ & 0.0051 & -0.0027 & 0.0044 & 0.0034 & 0.0059 & -0.0044 & 0.0047 & $-0.0183^{(a)}$ & 0.0057 \\
\hline \multicolumn{11}{|l|}{ Mother's education } \\
\hline Secondary & $-0.0089^{(b)}$ & 0.0041 & $-0.0094^{(b)}$ & 0.0037 & 0.0019 & 0.0048 & $0.0105^{(\mathrm{a})}$ & 0.0039 & 0.0059 & 0.0049 \\
\hline Trade, Vocational Training & $0.0157^{(\mathrm{c})}$ & 0.0094 & $0.0149^{(\mathrm{c})}$ & 0.0087 & $-0.0280^{(a)}$ & 0.0100 & $0.0426^{(\mathrm{a})}$ & 0.0094 & $-0.0451^{(a)}$ & 0.0094 \\
\hline College & 0.0049 & 0.0050 & $0.0369^{(\mathrm{a})}$ & 0.0051 & $-0.0380^{(a)}$ & 0.0057 & $0.0095^{(\mathrm{c})}$ & 0.0051 & $-0.0133^{(b)}$ & 0.0060 \\
\hline University & $0.0399^{(\mathrm{a})}$ & 0.0061 & $0.0128^{(\mathrm{b})}$ & 0.0053 & $-0.0945^{(a)}$ & 0.0057 & $0.0353^{(\mathrm{a})}$ & 0.0061 & 0.0065 & 0.0066 \\
\hline \multicolumn{11}{|l|}{ Province of residence: ${ }^{15}$} \\
\hline Quebec & $-0.0702^{(a)}$ & 0.0061 & $-0.0248^{(a)}$ & 0.0063 & $0.1637^{(\mathrm{a})}$ & 0.0115 & $-0.0394^{(\mathrm{a})}$ & 0.0062 & $-0.0294^{(a)}$ & 0.0082 \\
\hline Ontario & $0.0181^{(\mathrm{a})}$ & 0.0060 & $0.0158^{(\mathrm{a})}$ & 0.0056 & $0.1384^{(\mathrm{a})}$ & 0.0091 & $-0.0875^{(\mathrm{a})}$ & 0.0052 & $-0.0848^{(a)}$ & 0.0067 \\
\hline Manitoba, Saskat. & $-0.0816^{(a)}$ & 0.0054 & $-0.0491^{(\mathrm{a})}$ & 0.0055 & $0.1654^{(a)}$ & 0.0128 & $0.0174^{(\mathrm{b})}$ & 0.0074 & $-0.0522^{(a)}$ & 0.0081 \\
\hline Alberta & $-0.0165^{(b)}$ & 0.0066 & $-0.0518^{(a)}$ & 0.0049 & $0.2215^{(\mathrm{a})}$ & 0.0115 & $-0.0902^{(\mathrm{a})}$ & 0.0043 & $-0.0631^{(a)}$ & 0.0071 \\
\hline B.C. & $-0.0421^{(a)}$ & 0.0060 & $-0.0345^{(a)}$ & 0.0056 & $0.2539^{(\mathrm{a})}$ & 0.0117 & $-0.0430^{(a)}$ & 0.0054 & $-0.1343^{(a)}$ & 0.0058 \\
\hline Was working prior to college & $0.0393^{(\mathrm{a})}$ & 0.0036 & $-0.0054^{(b)}$ & 0.0025 & $-0.0203^{(a)}$ & 0.0039 & $-0.0072^{(\mathrm{c})}$ & 0.0043 & $-0.0064^{(\mathrm{c})}$ & 0.0034 \\
\hline \multicolumn{11}{|c|}{ Level of education before Enrolment: } \\
\hline College & $-0.0379^{(a)}$ & 0.0044 & $-0.0295^{(a)}$ & 0.0037 & $-0.0762^{(a)}$ & 0.0053 & $0.0976^{(\mathrm{a})}$ & 0.0054 & $0.0460^{(\mathrm{a})}$ & 0.0060 \\
\hline University & $0.0416^{(\mathrm{a})}$ & 0.0060 & $-0.0520^{(a)}$ & 0.0039 & $-0.0193^{(a)}$ & 0.0069 & $0.0496^{(\mathrm{a})}$ & 0.0060 & $-0.0198^{(a)}$ & 0.0067 \\
\hline Used student loans & $-0.0090^{(\mathrm{a})}$ & 0.0026 & $0.0300^{(\mathrm{a})}$ & 0.0025 & $-0.0617^{(\mathrm{a})}$ & 0.0031 & $0.0376^{(\mathrm{a})}$ & 0.0027 & 0.0030 & 0.0032 \\
\hline
\end{tabular}

$\overline{{ }^{15} \text { Province of residence twelve months prior to starting college }}$ 
Table 8 (Continued)

\begin{tabular}{|c|c|c|c|c|c|c|c|c|c|c|}
\hline & \multicolumn{2}{|c|}{$\begin{array}{c}\text { Education, Fine Arts, } \\
\text { Humanities }\end{array}$} & \multicolumn{2}{|c|}{$\begin{array}{c}\text { Social } \\
\text { Sciences }\end{array}$} & \multicolumn{2}{|c|}{$\begin{array}{l}\text { Commerce, } \\
\text { Business }\end{array}$} & \multicolumn{2}{|c|}{ Health } & \multicolumn{2}{|c|}{ Sciences } \\
\hline & Coef. & Std. Err. & Coef. & Std. Err. & Coef. & Std. Err. & Coef. & Std. Err. & Coef. & Std. Err. \\
\hline \multicolumn{11}{|l|}{ log Annual Earnings in: } \\
\hline $\begin{array}{l}\text { Education, Fine Arts, } \\
\text { Humanities }\end{array}$ & $0.1416^{(\mathrm{a})}$ & 0.0145 & $-0.0222^{(a)}$ & 0.0023 & $-0.0476^{(\mathrm{a})}$ & 0.0049 & $-0.0290^{(a)}$ & 0.0030 & $-0.0427^{(a)}$ & 0.0044 \\
\hline Social Sciences & $-0.0222^{(a)}$ & 0.0023 & $0.1147^{(\mathrm{a})}$ & 0.0118 & $-0.0369^{(a)}$ & 0.0038 & $-0.0225^{(\mathrm{a})}$ & 0.0023 & $-0.0330^{(a)}$ & 0.0034 \\
\hline Commerce, Business & $-0.0476^{(a)}$ & 0.0049 & $-0.0369^{(a)}$ & 0.0038 & $0.2035^{(\mathrm{a})}$ & 0.0208 & $-0.0482^{(a)}$ & 0.0049 & $-0.0708^{(a)}$ & 0.0073 \\
\hline Health & $-0.0290^{(a)}$ & 0.0030 & $-0.0225^{(\mathrm{a})}$ & 0.0023 & $-0.0482^{(\mathrm{a})}$ & 0.0049 & $0.1428^{(a)}$ & 0.0146 & $-0.0431^{(a)}$ & 0.0044 \\
\hline Sciences & $-0.0427^{(a)}$ & 0.0044 & $-0.0330^{(a)}$ & 0.0034 & $-0.0708^{(a)}$ & 0.0073 & $-0.0431^{(\mathrm{a})}$ & 0.0044 & $0.1896^{(a)}$ & 0.0194 \\
\hline \multicolumn{11}{|c|}{$\begin{array}{l}\text { Working prior to starting college } \\
\mathrm{x} \text { log annual earnings in: }\end{array}$} \\
\hline $\begin{array}{l}\text { Education, Fine Arts, } \\
\text { Humanities }\end{array}$ & $0.0821^{(\mathrm{a})}$ & 0.0140 & $-0.0129^{(a)}$ & 0.0022 & $-0.0276^{(a)}$ & 0.0047 & $-0.0168^{(a)}$ & 0.0029 & $-0.0247^{(a)}$ & 0.0042 \\
\hline Social Sciences & $-0.0129^{(a)}$ & 0.0022 & $0.0665^{(\mathrm{a})}$ & 0.0113 & $-0.0214^{(\mathrm{a})}$ & 0.0037 & $-0.0130^{(\mathrm{a})}$ & 0.0022 & $-0.0192^{(a)}$ & 0.0033 \\
\hline Commerce, Business & $-0.0276^{(a)}$ & 0.0047 & $-0.0214^{(\mathrm{a})}$ & 0.0037 & $0.1180^{(\mathrm{a})}$ & 0.0201 & $-0.0279^{(\mathrm{a})}$ & 0.0048 & $-0.0411^{(\mathrm{a})}$ & 0.0070 \\
\hline Health & $-0.0168^{(\mathrm{a})}$ & 0.0029 & $-0.0130^{(a)}$ & 0.0022 & $-0.0279^{(a)}$ & 0.0048 & $0.0829^{(a)}$ & 0.0141 & $-0.0250^{(a)}$ & 0.0043 \\
\hline Sciences & $-0.0247^{(\mathrm{a})}$ & 0.0042 & $-0.0192^{(\mathrm{a})}$ & 0.0033 & $-0.0411^{(\mathrm{a})}$ & 0.0070 & $-0.0250^{(a)}$ & 0.0043 & $0.1100^{(\mathrm{a})}$ & 0.0188 \\
\hline \multicolumn{11}{|c|}{ Female $x$ log annual earnings in: } \\
\hline $\begin{array}{l}\text { Education, Fine Arts, } \\
\text { Humanities }\end{array}$ & $-0.0403^{(a)}$ & 0.0152 & $0.0063^{(\mathrm{a})}$ & 0.0024 & $0.0135^{(\mathrm{a})}$ & 0.0051 & $0.0083^{(\mathrm{a})}$ & 0.0031 & $0.0121^{(\mathrm{a})}$ & 0.0046 \\
\hline Social Sciences & $0.0063^{(\mathrm{a})}$ & 0.0024 & $-0.0326^{(a)}$ & 0.0123 & $0.0105^{(\mathrm{a})}$ & 0.0040 & $0.0064^{(\mathrm{a})}$ & 0.0024 & $0.0094^{(\mathrm{a})}$ & 0.0036 \\
\hline Commerce, Business & $0.0135^{(\mathrm{a})}$ & 0.0051 & $0.0105^{(\mathrm{a})}$ & 0.0040 & $-0.0579^{(a)}$ & 0.0219 & $0.0137^{(\mathrm{a})}$ & 0.0052 & $0.0201^{(\mathrm{a})}$ & 0.0076 \\
\hline Health & $0.0083^{(a)}$ & 0.0031 & $0.0064^{(\mathrm{a})}$ & 0.0024 & $0.0137^{(\mathrm{a})}$ & 0.0052 & $-0.0406^{(a)}$ & 0.0153 & $0.0123^{(a)}$ & 0.0046 \\
\hline Sciences & $0.0121^{(\mathrm{a})}$ & 0.0046 & $0.0094^{(\mathrm{a})}$ & 0.0036 & $0.0201^{(\mathrm{a})}$ & 0.0076 & $0.0123^{(\mathrm{a})}$ & 0.0046 & $-0.0539^{(a)}$ & 0.0204 \\
\hline
\end{tabular}

Notes: Marginal effects are evaluated at the sample means for continuous variables, and the discrete change in the probability between 0 and 1 for dummy variables. (a), (b) and (c): significant at the level 1, 5 and 10 percent (Two-tailed test). 